\title{
Acute, but not constitutive, loss of endothelial $\beta 3$-integrin inhibits tumour growth and angiogenesis
}

\author{
Veronica Steri ${ }^{1}$, Tim Ellison ${ }^{1}$, Katherine Weilbaecher ${ }^{2}$, Kairbaan Hodivala-Dilke ${ }^{3}$, Stephen D Robinson ${ }^{*}$ \\ From São Paulo Advanced School of Comparative Oncology \\ Águas de São Pedro, Brazil. 30 September - 6 October 2012
}

\section{Background}

Angiogenesis, the formation of new vessels from pre-existing ones, is essential for tumour growth and metastasis. Endothelial cells play a central role in this process: they drive blood vessel formation in response to signals from the local environment, by a mechanism that is integrindependent. We are particularly interested in understanding what role $\alpha \mathrm{v} \beta 3$-integrin plays in governing tumour angiogenesis.

$\alpha v \beta 3$-integrin seemingly poses an ideal anti-angiogenic target. Its expression is vastly up-regulated in neo-angiogenic vessels, while its expression in quiescent vasculature is minimal. However, anti-angiogenic therapy targeting $\alpha v \beta 3$-integrin has proven somewhat disappointing. In part this likely relates to the fact that $\alpha v \beta 3$-integrin is not expressed solely by endothelial cells, but across a wide range of cell types that each contribute to angiogenesis. The aim of the research we present here is to elucidate the role of $\alpha v \beta 3$-integrin in tumour growth and angiogenesis as it is expressed specifically by endothelial cells.

\section{Methods}

We have crossed $\beta 3$-integrin floxed animals to two Cre transgenic models to delete $\beta 3$-integrin specifically in endothelial cells. In Pdgfb.Creert2 transgenic mice, $\beta 3$ integrin is deleted in a tamoxifen-inducible fashion in neoangiogenic endothelial cells, while in Tie1.Cre transgenic mice $\beta 3$-integrin is constitutively deleted in endothelial cells. In these animals, we have studied angiogenesis via the ex vivo aortic ring model, and in subcutaneoulsy grown B16F0 and CMT19T allograft tumours.

* Correspondence: stephen.robinson@uea.ac.uk

${ }^{1}$ University of East Anglia, School of Biological Sciences, Norwich, UK

Full list of author information is available at the end of the article

\section{Results}

In $\beta 3$-floxed/Pdgfb.Creert2 positive mice treated with tamoxifen, allograft tumours grow significantly smaller when compared to their growth in Cre negative littermate controls. This correlates with decreased microvascular density observed in Cre-postive compared to Cre-negative tumour sections. In contrast, constitutive deletion of endothelial $\beta 3$-integrin via Tie1.Cre leads to enhanced tumour angiogenesis. These findings are re-capitulated in the aortic ring model. VEGF-induced microvessel sprouting is inhibited in $\beta 3$-floxed/Pdgfb.Creert2 positive mice compared to Cre-negative littermates. In marked contrast, sprouting is enhanced in $\beta 3$-floxed/Tie1.Cre positive mice compared to $\beta 3$-floxed/Tie1.Cre negative mice.

\section{Conclusions}

These findings strengthen the argument that endothelially-expressed $\beta 3$-integrin remains a valid target of antiangiogenic tumour therapy. However, taken together, these data suggest that the timing and length of exposure to $\beta 3$-integrin endothelial genetic inhibition impacts on the angiogenic response. These data highlight the need to enhance our understanding of the molecular basis of angiogenesis in order to develop improved therapeutic treatments.

\section{Financial support}

University of East Anglia and the BigC Norfolk Cancer Charity.

\author{
Author details \\ ${ }^{1}$ University of East Anglia, School of Biological Sciences, Norwich, UK. \\ ${ }^{2}$ Washington University, St Louis, USA. ${ }^{3}$ Queen Mary's University London, \\ Barts Cancer Institute, London, UK. \\ Published: 4 April 2013
}


doi:10.1186/1753-6561-7-S2-07

Cite this article as: Steri et al: Acute, but not constitutive, loss of endothelial $\beta 3$-integrin inhibits tumour growth and angiogenesis. $B M C$ Proceedings 2013 7(Suppl 2):07.

Submit your next manuscript to BioMed Central and take full advantage of:

- Convenient online submission

- Thorough peer review

- No space constraints or color figure charges

- Immediate publication on acceptance

- Inclusion in PubMed, CAS, Scopus and Google Scholar

- Research which is freely available for redistribution

Submit your manuscript at www.biomedcentral.com/submit

C) BioMed Central 